\title{
Juncture Patterns of the Surabaya-citizen's Speech
}

\author{
Karsono, O.M.F. \\ Chinese Department, Petra Christian University, Siwalankerto 121- 131 Surabaya, INDONESIA \\ e-mail: miafarao@gmail.com
}

\begin{abstract}
In this paper, the researcher examines juncture patterns of Chinese language of Surabaya citizens who do not use Bahasa or Indonesian language as their mother tongue. The purpose is to see whether juncture patterns of local citizens can resemble the native speakers. The method that is used here is qualitative approach. The research on these juncture patterns is expected to contribute to the pattern map of the Surabaya citizen's speech in order to develop the Phonology Theory of Juncture. Based on the analysis of ten respondents, producing nine declarative sentences, seven interrogative sentences, six imperative sentences, and four exclamatory sentences, juncture patterns happen sometimes after a subject, after a predicate, between two words, and sometimes between two syllables within a word. Juncture happens before a word when the word is emphasized. The second finding is that juncture between syllables in a word is not always shorter than the one that happens between two words. The last finding is that there are two kinds of juncture, stopping and continuing juncture.
\end{abstract}

Key words: Pattern, juncture, Chinese language, sentence.

\section{INTRODUCTION}

It is generally known that one of the language functions is to communicate. It can be differentiated into the written and the spoken. In written language, punctuation marks are important. Two sentences that consist of the same words in the same sequence can have a different meaning, based on the punctuation mark used (Alwi, Dardjowidjojo, Lapoliwa, \& Moeliono, 2003, p. 84). In tone-language like Chinese, besides having tone, intonation, and stress that determine a sentence meaning, another influential element is the juncture. The function of suprasegmental element of juncture to the Chinese language in determining a sentence meaning can be seen in the following examples:
(1) bú gào nù bú shì rén
不 $^{35 \subset}$ 告 $^{51 \subseteq}$ 你 $^{214 \sqrt{ }}$ 不 $^{35}$ 是 $51 \subseteq$ 人 $^{35 \subset}$ 。
'Not reporting you not human'.

If the juncture in sentence (1) exists between the word $n \check{\imath}$ (你) [you] and bú (不) [not], it will make sentence (1a)
(1a) bú gào nǐ / bú shì rén

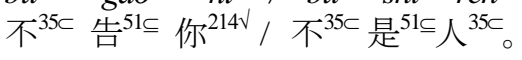 'not reporting you /is not human'.

Sentence (1a) means 'not reporting you, is not human.' Another meaning occurs when a juncture exists between the

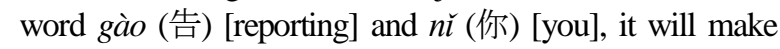
sentence (1b)
(1b) bú gào /nǐ bú shì rén 不 $^{35 \subset}$ 告 ${ }^{51 \subseteq /}$ 你 $^{214 \sqrt{ }}$ 不 $^{35 \subset}$ 是 $51 \subseteq$ 人 $^{35 \subseteq 。}$ 'not reporting / you are not a human'

Sentence (1b) means 'when you are not reporting, you are not a human.' It is clear that juncture in a statement influences its meaning. According to Xíng (2001), a juncture in Chinese language has two functions. First is grammatical juncture, which appears in a natural statement. Second is logical juncture, which occurs in a sentence to signalize the speaker's purpose (p. 110). Since a juncture can influence the meaning of a sentence, the researcher will examine the juncture patterns.

Related to the type of sentence, according to Hú (2006), a sentence is a language unit that can reflect a speaker's purpose clearly while communicating (p. 80). The meaning of a sentence is based on the context of the communication and the speaker, while the type of the sentence, used in the communication, includes declarative, interrogative, imperative and exclamatory sentences. Therefore, the researcher examines juncture patterns of Surabaya citizen related to those four types of sentence. Respondents are Surabaya citizen, who are chosen based on a pre-survey that the people in this region have various strong local dialects especially the 'Suroboyoan' dialect. Their utterances are examined to understand whether they have diverse variation of juncture patterns or not.

Since the researcher examines juncture patterns, the underlying theories of communicative concept from Firth and Halliday are used, especially the seven language functions of Halliday and Ruqaiya (1976), to analyze the juncture function in Surabaya people's discourse (pp.1117). Moreover, I will also apply the effect of seven kinds of sentence-communication meaning by Leech (2003, pp. 1935 ), and the theory of phonology characteristic of Chinese language about juncture and morpheme of Chinese words itself. 


\section{JUNTURE IN CHINESE LANGUAGE (Tíngyán / 停延)}

A Juncture in Chinese language is termed tíngyán (停延). This term means when we speak loudly, a juncture happens within a paragraph or a sentence. There are two kinds of juncture in Chinese language. The first is continuing juncture or yánlián (延连) which occurs because of a prolonged sound (音长). The second is tíngdìn (停顿) or stopping juncture which occurs because of an absent sound. Continuing juncture or yánlián (延连), based on the time lapse, is distinguished into two types of sound connection, short and long. Stopping juncture or tíngdùn (停顿) is also distinguished into tíngxie (停歇) and dùnxie (顿歇). The sound fragmentation in a sentence is called dùnxie (顿歇), while the fragmentation that occurs in a bigger unit language like in sentence combinations or paragraphs is called tingxie (停歇). Generally, the time lapse in tingxie (停歇) lasts longer than in dìnxie (顿歇). These juncture arrangements are frequently functioned to differentiate speech meaning (Wú, 2000, p. 37). Junctures occur more frequently in Chinese language than in English. This happens because the more junctures occur, the more it can emphasize the meaning and the feeling of the speaker. Stopping juncture or tíngdìn (停顿) happens because of physical human needs. This juncture is needed by the speaker to take breath, or to express feeling so that the addressee has time to understand the intended meaning of the discourse.

The junctures here are similar to break or joint in the discourse of Indonesian language. Chaer (2007) says that a juncture is called a break because a stop happens, and it is called a joint because between the connection of one element and another the stopping process exists (p.122). A juncture in every language has its own characteristics, clear or unclear (Marsono, 2006, p. 117). According to its position within a context of a sentence, a juncture can be distinguished into internal juncture or in Chinese language nèibù tíngdùn (内部停顿) and open juncture or wàibù tíngdùn (外不停顿) (Wú, 2000, p. 41). An internal juncture separates one syllable from another, within a word, and it is commonly put in with a tally mark $(+)$. For example sentence (2) and (3)

(2) xiàn+zài (现在) 'now'

(3) diàn+dēng (电灯) 'lamp'

An open juncture shows a greater boundary than a syllable, which is usually still distinguished into a juncture between words in phrases, marked with an inverted slash (/); a juncture between phrases in a clause, marked with a double inverted-slash (//); and a juncture between sentences in a discourse, marked with a double cross (\#). Example sentence (4) and (5)

(4) Nì de yú //gān/ zài năr măi\#

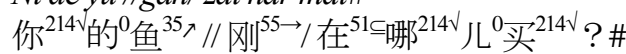

(5) Nì de yú gān // zài năr măi?\# 你 ${ }^{214}$ 的 ${ }^{0}$ 鱼 ${ }^{35}+$ 缸 ${ }^{55 \rightarrow} / /$ 在 $^{51} \subseteq^{\text {哪 }}{ }^{214}$ 儿 $^{0}$ 买 $^{214 \downarrow}$ ?\#
If a longer juncture occurs between the word yú and gāng, the sentence has a meaning 'Where did you buy this fish?' If a long juncture appears between the words gāng and zài, the sentence has another meaning 'Where did you buy this aquarium?' An open juncture between words in a phrase can be seen in sentence (6).

(6) Wǒ zàn chéng tā yě zàn chéng nǐ zěn me yàng?

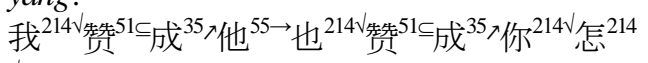$$
\vee^{{ }^{0}}{ }^{\text {样 }}{ }^{51 \subseteq ?}
$$

If a juncture occurs at Wǒ zànchéng tā / yě zànchéng ň̆/ zěnmeyàng?, the sentence means 'I agree with him, also agree with you, understood?' If a juncture occurs at Wo zànchéng / tā yě zànchéng/ nǐ zěnmeyàng?, The sentence means 'I agree, he does also agree, what about you?' Because a juncture can influence the meaning of a sentence, it is necessary to examine how it affects the discourse of Surabaya citizen.

According to its function in a sentence, there are two kinds of juncture in Chinese language, grammatical juncture and stress meaning juncture. Grammatical juncture reflects the grammatical relationship in a discourse sentence (Hú, 1993, p. 147; Xíng \& Wàng, 2009, p. 141). First, this grammatical juncture in a written language can be expressed with reading marks, like commas, periods, etc. The duration of the juncture is symbolized with the reading marks. For example juncture time of a stop (.), question mark (?), and shout-out marks (!) are longer than semi-colons (;) or colons (:) (Huáng \& Liào, 2005, p. 124). This juncture is used to differentiate the types of words, word meaning, and language structures which produce different meanings. A clear example is shown in the following example (Hú, 1993, p.147).

(7) Wǒ /gèn tā xué yīng yǔ, ň̆ /gēen Xiăo lǐ xué fã yŭ.

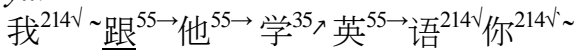
跟 $55 \rightarrow$ 小 $^{214 \sqrt{ }}$ 李 $^{214 \sqrt{ }}$ 学 $^{35}$ 法 $^{214 \sqrt{ }}$ 语 $^{214 \sqrt{ }}$ 。

'I / learn English from him // you / learn France from Xiaoli ' " $g \bar{e} n$ " is a preposition)

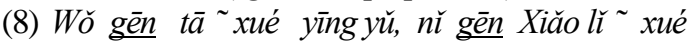
fă $y \check{u}$.

$$
\begin{aligned}
& \text { 我 }^{214 \sqrt{ }} \text { 跟 }^{55 \rightarrow} \text { 他 }^{55 \rightarrow ~ \sim ~} \text { 学 }^{35} \text { 入 英 }{ }^{55 \rightarrow} \text { 语 }^{214 \sqrt{ }} \text { 你 }^{214 \sqrt{ }} \\
& \text { 跟 } 55 \rightarrow \text { 小 }^{214 \sqrt{ }} \text { 李 }^{214} \text { 学35 } \\
& \text { 法 }^{214 \sqrt{ }} \text { 语 }^{214 \sqrt{ }} \text { 。("gēen" is connective word) }
\end{aligned}
$$

'I and him learn English // you and Xiaoli learn France'

Secondly, a stress meaning juncture is used to emphasize the intended meaning, or the emotion of the speaker.

\section{SEMANTIC IN CHINESE LANGUAGE}

A discourse, when it is continuously segmented, will finally reveal the smallest unit of sound called phoneme. On the greater heights of phonemes, there are higher level unit forms called syllable. This syllable has a non-functional characteristic and beyond it there is a functional unit called morpheme. So, morpheme is the smallest grammatical unit 
which has meaning. For example, the word măhu (马虎) is a morpheme with a phonological form măhu which means 'not serious'. This is a combination form of phonemes with a meaning, and cannot be separated into smaller language units with meaning.

A morpheme also represents the smallest bounding of phonological and semantic elements, and it is the smallest grammatical part of a language. The morpheme of spoken Chinese language is shown as syllable, while in written language it is shown as a Chinese character. A morpheme in Chinese language usually consists of one syllable and one word in its written language. Nonetheless, there are morphemes with two or more syllables; and when those are written, the words consist of two or more Chinese characters. For example in sentence (11) (Hú, 1993, p. 231).

(9) Lŭ Xùn / Bīng Xīn / Zhū Zì qīng / de / zuò pìn /shì /wǒ /men /de /fàn /běn

鲁迅/冰心/朱自清/的/作品/是/我/ 们/的/范/本

In the above sentence, the words $L \breve{u} X \grave{u} n$, Bīng Xīn are morphemes consisting of two syllables, while Zhü Ziquing is a morpheme consisting of three syllables. Those morphemes, although consisting of more than one syllable, only have one meaning.

The most important, a word must be the smallest independent unit. For example, when the word yizhì (意志) 'intention', is separated into yì (意) and zhì (志), it will not have any meaning (p. 241). Another way to understand whether a language component belongs to a word or not, we can extend it by adding a certain language component. If the extension changes the meaning, the phoneme unit is a word. For example, a phoneme combination mălù (马路), when it is added with a language component $d e$ (的), it will result in a sound of language component mă de lù which means 'horse trail', while the actual meaning is 'highway'.

Chinese words, according to the structure, are divided into three kinds, single morpheme words, two or more morphemes words, and abbreviation words (Liú, Pān, \& Gù, 2001, p.10). Single morpheme words are constructed by one morpheme, generally consist of one syllable. These kinds of words dominated the ancient era. Along with the modernization, nowadays, double morpheme words are on the top list. Single morpheme words, when they are spoken, consist of one syllable, and in the written form, consist of one Chinese character. Words with single morphemes are generally used to express daily-life items (for example the words mă / 马 'horse', māo / 猫 'cat', tiān / 天 'day') (Xíng, 2003,p. 126).

Beside of consisting one syllable, there are single morpheme words that also consist of two or more syllables. Multi morpheme words are usually derived from foreign language like luóji (逻辑) 'logic'. There are words that also consist of two syllables with identical consonant sound (făngfúl 仿佛 'resemble'), or words with identical vocal sound like (hútu /糊涂 'spider'), or inherited ancient words like (zhóuli / 妯娌 'a term of the relationship between older brother's wife and younger brother's wife') (Liú, et al., 2001, p. 11).

Words consisting of two or more morphemes, observed from the construction method, can be distinguished into repeating words, decendant words, and substraction or combination words. Like the word bàba (爸爸) 'father', or the repetition of two morphemes behind another morpheme, like liàng jīngjīng (亮晶晶 ) 'shining'. Repeating words can also be constructed by adding another word that has no meaning, like huāngli huāngzhang (慌里慌张) 'nervous'. Decendant words are constructed by combining the rootword with affixes, like dúzhe (读者) means 'book reader'. The word in front, $d \dot{u}$ (读), is the prominent word, while the supplement is functioned as a syntax that limits or broadens the original meaning of the root-word. Substraction words are constructed by omitting several morphemes, like chüzhōng 初中 which is a substraction of chüjízhōngxué 初级中学 (junior high shool).

\section{SYNTAX IN CHINESE LANGUAGE}

A sentence is the smallest language unit in the form of written or spoken to express a complete thought. Types of sentences in Chinese language can be reviewed from the (a) number of clauses, (b) syntax structure (c) element completeness, and (d) arrangement of subject and predicate. Since in this paper the researcher only examines the juncture pattern of sentences related to the distribution of the syntax characteristics, the explicated theories are only used around the theories of sentence structure based on the syntax characteristic. According to the communicative function, as a discourse character, Chinese sentences usually are divided into (1) declarative or message sentences, (2) imperative or command sentences, (3) interrogative or question sentences, and (4) exclamatory or shout-out sentences (Fáng, 2008, p. 91).

Chinese Declarative Sentences are the sentences that narrate an event, reveal something, or comment on something. Usually they inform something new to the addressee. In written language, these sentences are most frequently used. Declarative sentences can be classified into several kinds. The important thing is that it must have words to tell something, depict something, describe something or comment on something (Liú et al. 2001, p. 25). Different choice of words as the marker of declarative sentences will produce different kinds of declarative sentences. Frequently these marking words are used simultaneously in a sentence.

Chinese interrogative sentences are used to ask something, especially in spoken language. It does not confirm something, or deny something. A few specific words are frequently used in question sentences, like $m a$ 吗, or shibushi 是不是. Intonation is usually increasing at the end of an interrogative sentence. Chinese commanding sentences are frequently used to command, or plead, or forbid something. The intonation of a commanding sentence is usually decreasing at the end of the sentence The main function of Chinese shout-out sentences is to express 
feelings, like joy or sadness. So, a shout-out sentence is not functioned to inform something. The intonation of a shoutout sentence is usually started with an ascending tone at the beginning, and a descending tone at the end of the sentence. Words that are frequently used to express speaker feelings are $a$ (啊), le (了), la啦 (Yè \& Xú, 1997, p. 91).

\section{RESEARCH METHOD}

A descriptive method is used with qualitative approach. The basic idea of applying the method and the approach is because qualitative study can understand the plot/narration chronologically and guide the researcher to discover unexpected result during the research process (Miles \& Huberman, 1992, p. 1). The researcher has made observations to know which places that are usually used by the Surabaya citizen to communicate in Chinese. Persuasive approach is used in order to get data of discourse from the subjects while they are communicating in a relaxed situation. To get more people as the subjects of the research, a technique called snowball sampling is used (Dörnyei, 2007, p. 129). A stimulating technique sometimes seems like off target, but it actually conceals special purposes (Samarin, 1988, p. 162). The process of collecting discourse data goes naturally, so there are no preparations made by the subjects. Seeing from the scope of time, this research uses synchronic approach, which refers to a research that is limited on a certain time.

Research subjects are Surabaya citizens who have or do not have identity cards, but are working in Surabaya. Furthermore, the subjects are chosen based on the ability to communicate in Chinese, those who are fluent in BT, equal to the standard examination of HSK (Hànyǔ Shuíping Kăoshi / 汉语水平考试) level 6 to 8 (highest intermediate HSK level). The reason of applying those qualifications for the chosen subjects is that, since subjects with lower HSK are rarely able to communicate in Chinese easily although most of them still communicate in Indonesian language. The subjects may come from Chinese and non-Chinese descendants. The research data of discourse between the subject and the researcher or the subject among other subjects are transformed into transcript data. The transcript data are processed using Praat program to see the junctures, and then the observed patterns are analyzed to confirm the conclusions. The research has done the analyses of 26 sentences, but this paper only provides one example from each kind of sentences (declarative/question/ command/ shout-out).
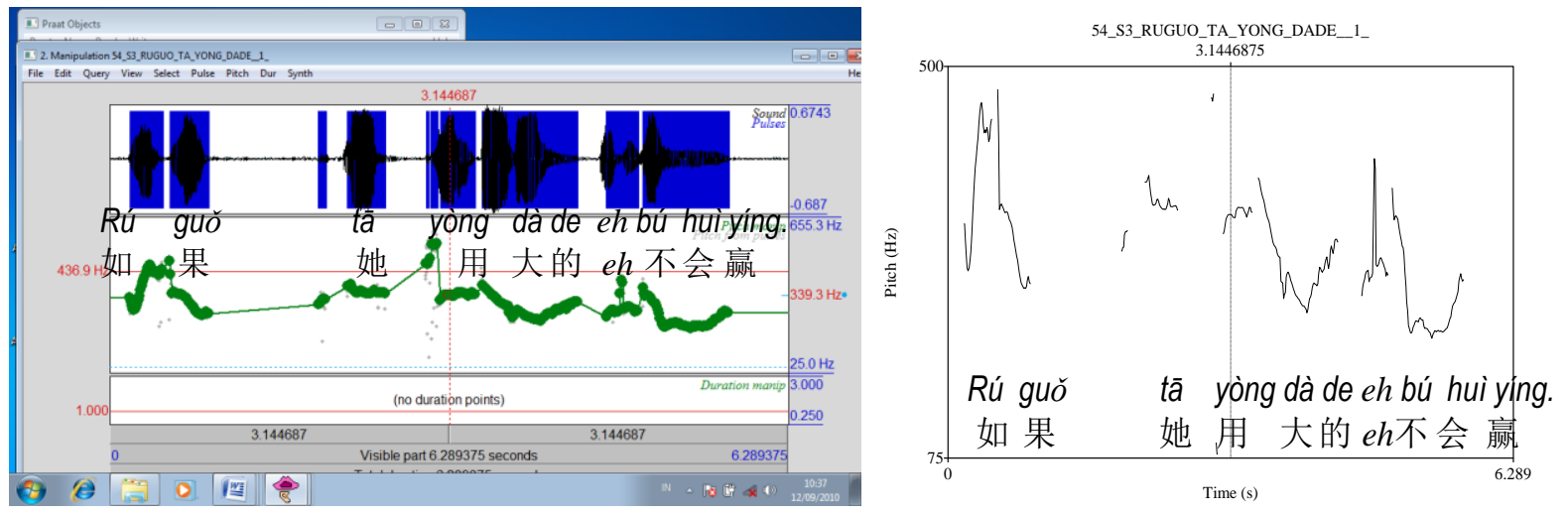

Fig. 1. Two Praat graphs distinguishing Stopping \& Continuing Juncture

Table 1. Juncture and words spoken in Declarative sentence S3/24/KB

\begin{tabular}{lcccc}
\hline \multicolumn{1}{c}{ Word } & Word code & $\begin{array}{c}\text { Start of discourse time in } \\
\text { second }\end{array}$ & $\begin{array}{c}\text { End of discourse time in } \\
\text { second }\end{array}$ & Time lapse in second \\
\hline 1. Rú 如 & $35 \subset$ & 0,183 & 0,484 & 0,301 \\
Stopping juncture & & 0,484 & 0,553 & 0,069 \\
2. guó & $214 \sqrt{ }$ & 0,553 & 0,909 & 0,356 \\
Stopping juncture & & 0,909 & 2,191 & 1,282 \\
3. $t \bar{a}$ 她 & $55 \rightarrow$ & 2,191 & 2,554 & 0,363 \\
Stopping juncture & & 2,554 & 3,071 & 0,517 \\
4. yòng用 & $51 \subseteq$ & 3,071 & 3,388 & 0,317 \\
Stopping juncture & & 3,388 & 3,450 & 0,062 \\
5. dà大 & $51 \subseteq$ & 3,450 & 3,736 & 0,286 \\
6. de的 & 0 & 3,736 & 4,330 & 0,594 \\
Stopping juncture & & 4,330 & 4,608 & 0,278 \\
Eeeh & $35 \subset$ & 4,608 & 4,747 & 0,139 \\
7. bu不 & & 4,747 & 4,894 & 0,157 \\
Stopping juncture & $51 \subseteq$ & 4,894 & 4,940 & 0,046 \\
8. hui & $35 \subset$ & 4,940 & 5,149 & 0,209 \\
9. yíng赢 & 5,149 & 5,705 & 0,556 \\
\hline
\end{tabular}




\section{JUNTURE PATTERNS IN CHINESE SENTENCES}

Here, four juncture patterns from the 26 research data are displayed and analyzed. Each sentence is displayed in two different Praat graphs to find out their types and positions.

1) Rú guǒ tā yòng dà de eeh bú huì yíng (Declarative sentence)

如果她用大的 eeh不会赢。

'If she uses the big one, she won't win' (S3/24/ KB).

By comparing the two Praat displays, it can be seenthat all types of junctures are stopping junctures, because all juncture lines (left picture) show voids (right picture). Following Table 1 display juncture position with the time lapse (in seconds).

The use of junctures in S3 discourse is to emphasize the object of the sentence hence it is included in the thematic meaning and the juncture function. In this declarative sentence of $\mathrm{S} 3$, the juncture is functioned as the representation of this game to explain that his sister cannot win, unless, marked by the juncture after the word de 的 The researcher observesthat the longest juncture occurs between the word rúguó 如果 and the word $t \bar{a}$ 她 $(1,282$ seconds), and followed by the juncture between the word $t \bar{a}$ 她and the word yòng 用( 0,517 seconds). These junctures exist between an adverb and the subject. These junctures occur between three-tone words and one-tone words. It also appears between a word that consists of two syllables, like rúguó 如果 for 0,069 seconds; this juncture is not the shortest time lapse. In this sentence, junctures happen not only before a four-tone word, as shown in the following Table 2 .

Table 2. Juncture relationship with the Tone Words

\begin{tabular}{|c|c|c|}
\hline Between words & Tone & Number code \\
\hline rú如 - guǒ果 & $2-3$ & $35 \lambda-214 \sqrt{ }$ \\
\hline guó果 - tāt她 & $3-1$ & $214 \sqrt{ }-55 \rightarrow$ \\
\hline tā她 - yòng用 & $1-4$ & $55 \rightarrow-51 \subseteq$ \\
\hline yòng用 - dà大 & $4-4$ & $51 \subseteq-51 \subseteq$ \\
\hline$d e$ 的 $-b u$ 不 & $0-2$ & $0-35 \pi$ \\
\hline$b u$ 不 $-h u i$ 会 & $2-4$ & $35 \nearrow-51 \subseteq$ \\
\hline
\end{tabular}

2) Wén Shèng, nǐ xiàn zài bú yào wán hăo buhăo? (Question sentence)

文 盛你 现 在不要 玩 好不好?

'Wén Shèng, will you please stop playing game now?' (S4/14/KT)

By comparing the two Praat displays, the reseracher observes that in the question sentence S4/14/KT two junctures occur, all of them are stopping junctures tíngdùn (停顿, because both juncture lines (left picture) show voids (right picture). Following Table 3 display of juncture position with the time lapse (in seconds).

Junctures in S4 discourse have affective meanings and are functioned interactively. The affective meaning is shown by the occurrence of junctures after subject and someone's name. (between Wén Shèng 文盛 and $n \check{~}$ 你). Here, a
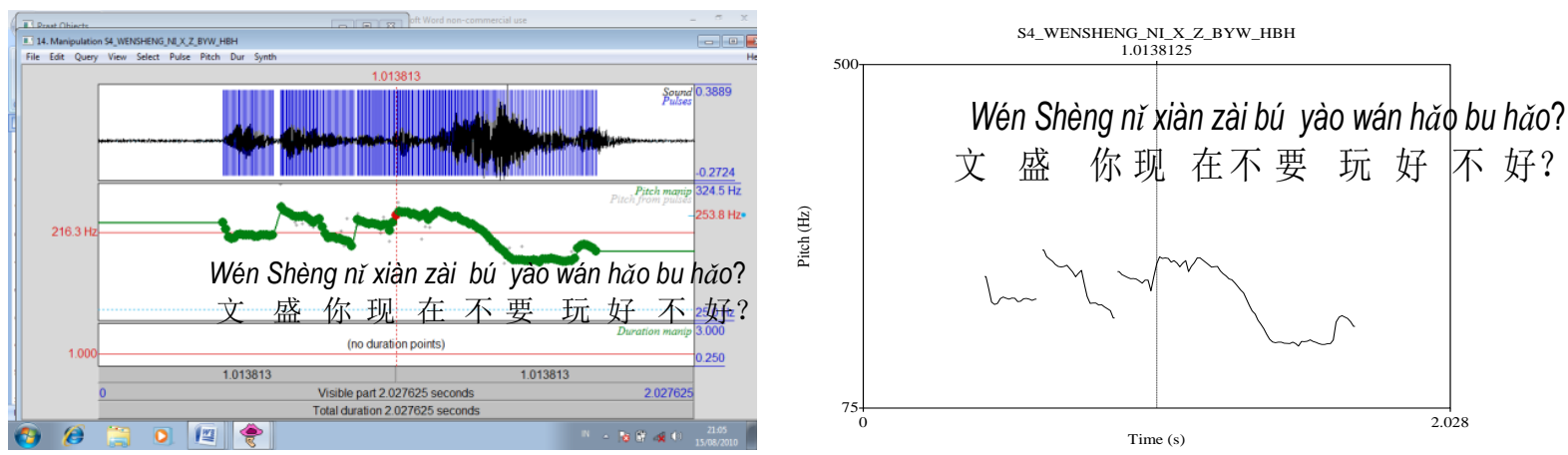

Fig. 2. Two Praat graphs distinguishing Stopping \& Continuing Juncture

Table 3. Juncture and words spoken in Declarative sentence S4/14/KT

\begin{tabular}{lcccc}
\hline \multicolumn{1}{c}{ Word } & Word code & $\begin{array}{c}\text { Start of discourse time in } \\
\text { second }\end{array}$ & $\begin{array}{c}\text { End of discourse time in } \\
\text { second }\end{array}$ & Time lapse in second \\
\hline 1. Wén 文 & $35 \subset$ & 0,060 & 0,243 & 0,183 \\
Stopping juncture & & 0,243 & 0,255 & 0,012 \\
2. Shèng 盛 & $51 \subseteq$ & 0,255 & 0,387 & 0,132 \\
3. nǔ 你 & $214 \sqrt{ }$ & 0,387 & 0,502 & 0,115 \\
Stopping juncture & & 0,502 & 0,514 & 0,012 \\
4. xiàn 现 & $51 \subseteq$ & 0,514 & 0,624 & 0,110 \\
5. zài 在 & $51 \subseteq$ & 0,624 & 0,746 & 0,122 \\
6. bú 不 & $35 \subset$ & 0,746 & 0,825 & 0,079 \\
7. yào 要 & $51 \subseteq$ & 0,825 & 0,977 & 0,152 \\
8. wán 玩 & $35 \subset$ & 0,977 & 1,128 & 0,151 \\
9. hăo 好 & $214 \sqrt{ }$. & 1,128 & 1,252 & 0,124 \\
10. bú 不 & 0 & 1,252 & 1,373 & 0,121 \\
11. hăo 好 & $214 \sqrt{ }$ & 1,373 & 1,427 & 0,054 \\
\hline
\end{tabular}


juncture is used to express speaker's feeling that consists of stressing, in order to get his request fulfilled. Interaction function is seen from the juncture between the subject $n \check{\iota}$ 你 and the predicate xiànzài 现在. According to the word structure, junctures happen within syllables of one word, and between two words. It also shows a tendency that junctures exist before four-tone words, as shown in the next Table 4

Table 4. Juncture relationship with the Tone Words

\begin{tabular}{lcc}
\hline Between words & Tone & Number code \\
\hline Wén 文-Shèng 盛 & $2-4$ & $35 \subset-51 \subseteq$ \\
$N \check{c}$ 你-xiàn 现 & $3-4$ & $214 \sqrt{ }-51 \subseteq$ \\
\hline
\end{tabular}

3) Nǐ de gāngqín de shū gěi lăoshī kàn, kuàidiàn! (Command sentence)

你的钢琴的少给老师看, 快点!

'Show your piano book to the teacher, quick!' $(\mathrm{S} 4 / 17 / \mathrm{KP})$

By comparing the two Praat graphs above, it is proven that in commanding sentence S4/17/KP six junctures occur; twice are continuing junctures or yánlián (延车) and the

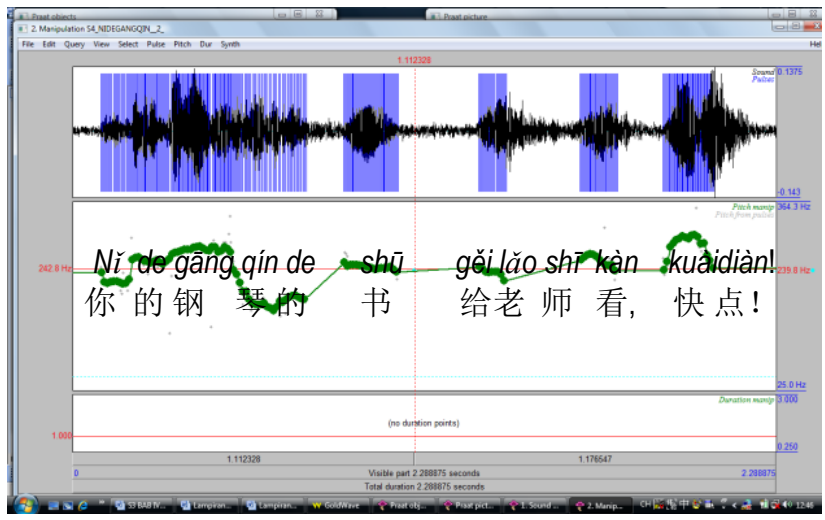

other four are stopping junctures or tíngdùn (停顿. Continuing junctures show a constant line, both of the left or right figures, while stopping junctures show constant lines in the left figure, but voids in the right figure. Juncture positions and the time lapse of sentence S4/17/KP are shown in the next Table 5.

The researcher finds out that a continuing juncture occurs twice, between the word ni你 and the word $d e$ 的 between the syllable gāng 钢 and the syllable qin 琴(from the word gāngqin 钢琴). The stopping juncture occurs four times, between the words $d e$ 的 $-s h \bar{u}$ 书 $s h \bar{u}$ 书 ge $i$ 给 between the syllables $s h \bar{\imath}$ 师(from the word lăosh $\bar{\imath}$ 老互 - the word kà 看, and between the word kàn 看the syllable kuài 快 (from the word kuàidiàn 快点). If it is cautiously observed, the time lapse of continuing junctures is lesser than the time lapse of stopping junctures. Most of the junctures occur between words, and only once within a word consisting of two syllables, that is the word ganngqin 钢挎琴. Besides, junctures also tend to occur in word combinations that are followed with various tones, as shown in the following Table 6 .

Fig. 3. Two Praat graphs distinguishing Stopping \& Continuing Juncture

Table 5. Juncture and words spoken in Commanding sentence S4/17/KP

\begin{tabular}{|c|c|c|c|c|}
\hline Word & Word code & $\begin{array}{l}\text { Start of discourse time in } \\
\text { second }\end{array}$ & $\begin{array}{l}\text { End of discourse time in } \\
\text { second }\end{array}$ & Time lapse in second \\
\hline $1 . N i$ 你 & $214 \sqrt{ }$ & 0,089 & 0,184 & 0,095 \\
\hline Continueing juncture & & 0,184 & 0,195 & 0,011 \\
\hline 2. $d e$ 的 & 0 & 0,195 & 0,316 & 0,121 \\
\hline 3. gāng 钢 & $55 \rightarrow$ & 0,316 & 0,514 & 0,198 \\
\hline Continueing juncture & & 0,514 & 0,574 & 0,060 \\
\hline 4. qin 琴 & $35 \subset$ & 0,574 & 0,647 & 0,073 \\
\hline 5. $d e$ 的 & 0 & 0,647 & 0,758 & 0,111 \\
\hline Stopping juncture & & 0,758 & 0,882 & 0,124 \\
\hline 6. $s h \bar{u}$ 书 & $55 \rightarrow$ & 0,882 & 1.058 & 0,176 \\
\hline Stopping juncture & & 1,058 & 1,323 & 0,265 \\
\hline 7. gěi 给 & $214 \sqrt{ }$ & 1,323 & 1,402 & 0,079 \\
\hline 8. lăo 老 & $214 \sqrt{ }$ & 1,402 & 1,451 & 0,049 \\
\hline 9. $s h \bar{\imath}$ 师 & $55 \rightarrow$ & 1,451 & 1,495 & 0,044 \\
\hline Stopping juncture & & 1,495 & 1,739 & 0,244 \\
\hline 10. kàn 看 & $51 \subseteq$ & 1,739 & 1,859 & 0,120 \\
\hline Stopping juncture & & 1,859 & 1,970 & 0,111 \\
\hline 11. kuài 快 & $51 \subseteq$ & 1,970 & 2,086 & 0,116 \\
\hline 12. diàn 点 & $51 \subseteq$ & 2,086 & 2,134 & 0,048 \\
\hline
\end{tabular}


Table 6. Juncture relationship with the Tone Words

\begin{tabular}{|c|c|c|}
\hline Between words & Tone & Number code \\
\hline$n \check{l}$ 你- $d e$ 的 & $3-0$ & $214 \sqrt{-0}$ \\
\hline gāng 钢- qín 琴 & $1-2$ & $55 \rightarrow-35 \subset$ \\
\hline$d e$ 的- $s h \bar{u}$ 书 & $0-1$ & ringan $-55 \rightarrow$ \\
\hline$s h \bar{u}$ 书-gěi给 & $3-3$ & $55 \rightarrow-214 \sqrt{ }$ \\
\hline$s h \bar{\imath}$ 师- $k \grave{a}$ 看 & $1-4$ & $55 \rightarrow-51 \subset$ \\
\hline kàn 看 kuài 快 & $4-4$ & $51 \subseteq-51 \subseteq$ \\
\hline
\end{tabular}

Junctures in this $\mathrm{S} 4$ discourse have a thematic meaning and are functioned as an instrument. The thematic meaning can be seen from the occurred junctures, after the subject, before the predicate and before the object, which means the theme is focused on the predicate and the object. While junctures as an instrument function occur before the commanding instrument of the word kuàidiàn 快点 (quick!).

4) Wah! Lăo shī, jiào shì li zhēn lěng a! (Shout-out sentence)

Wah! 老师, 教室里真冷 啊!

'Hey! Teacher, the class is really cold, yeah!' (S6/39/KS)

By comparing the two Praat graphs, the researcher observes that within shout-out sentence S6/39/KS, two kinds of junctures occur, once of a continuing juncture or yánlián (延车) between the word shi 室and the word $l i$ 里 and five

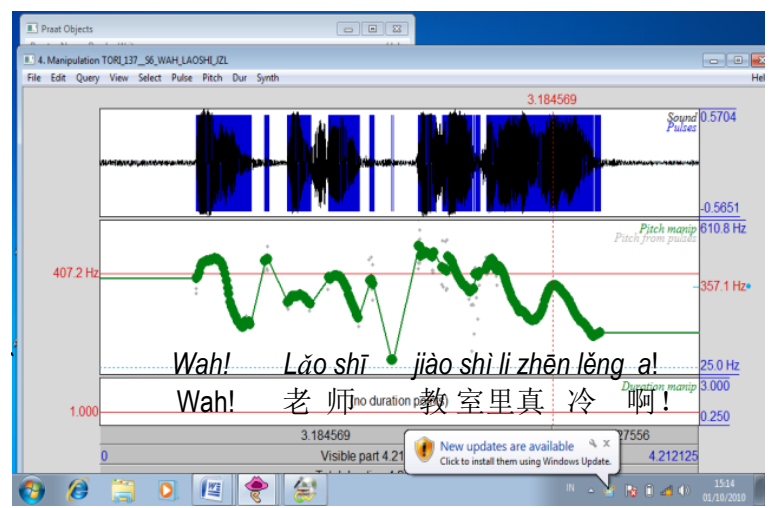

times of a stopping juncture or tíngdìn (停顿, between the word wah and the word Lăosh $\bar{\imath}$ 老市, between syllable Lăo 老 and syllable $s h \bar{\imath}$ 师(from the word $s h \bar{l}$ 老市; between the word $s h \bar{\imath}$ 老市and the word jiàoshi 教室, between syllable jiào教and syllable shi 室 (from the word jiàoshi 教室); between the word $l i$ 里 and word zhen 真 To know the different time lapse of these junctures, look at the following Table 7.

According to the theory of juncture, a sentence consists of two types of junctures, stopping and continuing junctures. A continuing juncture occurs only once, that is between the word jiàoshi 教室 and word $l i$ 里 Other junctures are the stopping junctures. The longest time lapse occurs between the words shi 老币-jiàoshì 教室lasting for 0,476 second and becomes the boundary between the subject and predicate of sentence S6/39/KS. The second longest is the stopping juncture between the shout-out word wah (hey) at the beginning of the sentence and the following words with a 0,235 second time lapse. It seems that junctures between two syllables in one word, syllable Lăo 老 and syllable shī 师 (from the word Lăoshī 老互) are relatively longer compared to junctures between two words. A tendency of junctures also occurs in a word combination that followed by four-tone and one-tone words, which means junctures occuring at a combination of two words with the last word is spoken at tone level (5), as seen in the following Table 8 .

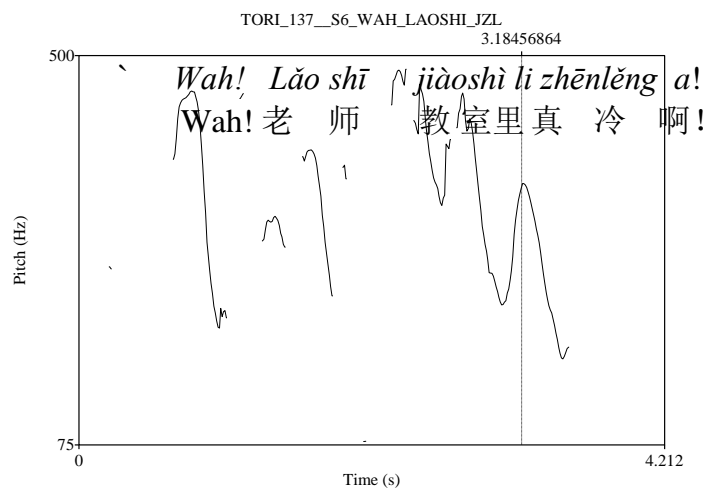

Fig. 4. Two Praat graphs distinguishing Stopping and Continuing Juncture

Table 7. Juncture and words spoken in Commanding sentence S6/39/KS

\begin{tabular}{lcccc}
\hline \multicolumn{1}{c}{ Word } & Word code & $\begin{array}{c}\text { Start of discourse time in } \\
\text { second }\end{array}$ & $\begin{array}{c}\text { End of discourse time in } \\
\text { second }\end{array}$ & Time lapse in second \\
\hline 1. Wah! & An expression & 0,681 & 1,064 & 0,383 \\
Stopping juncture & & 1,064 & 1,317 & 0,253 \\
2. Lăo 老 & $214 \sqrt{ }$ & 1,317 & 1,483 & 0,166 \\
Stopping juncture & & 1,483 & 1,607 & 0,124 \\
3. shī 师 & $55 \rightarrow$ & 1,607 & 1,772 & 0,165 \\
Stopping juncture & & 1,772 & 2,248 & 0,476 \\
4. jiào 教 & $51 】$ & 2,248 & 2,352 & 0,104 \\
Stopping juncture & & 2,352 & 2,408 & 0,056 \\
5. shì 室 & $51 \searrow$ & 2,408 & 2,435 & 0,027 \\
Continueing juncture & & 2,435 & 2,455 & 0,020 \\
6. li 里 & 0 & 2,455 & 2,672 & 0,217 \\
Stopping juncture & & 2,672 & 2,724 & 0,052 \\
7. zhēn 真 & $55 \rightarrow$ & 2,724 & 2,797 & 0,073 \\
8. léng 冷 & $214 \sqrt{ }$ & 2,797 & 3,122 & 0,325 \\
9. $a$ 啊 & 0 & 3,122 & 3,521 & 0,399 \\
\hline
\end{tabular}


Table 8. Juncture relationship with the Tone Words

\begin{tabular}{llc}
\hline Between words & Tone & Number code \\
\hline Lăo 老 $s h \bar{\imath}$ 师 & $3-1$ & $214 \sqrt{ }-55 \rightarrow$ \\
$s h \bar{\imath}$ 师-jiào 教 & $1-4$ & $55 \rightarrow-51 \searrow$ \\
jiào 教 $s h \grave{i}$ 室 & $4-4$ & $51 \searrow-51 \searrow$ \\
$l i$ 里- $z h \bar{e} n$ 真 & $3-1$ & $214 \sqrt{ }-55 \rightarrow$ \\
\hline
\end{tabular}

Function as the characteristic. Each focused theme that is emphasized has a juncture occurs in front of it. This occurs in front of the word zhēnlěng 真冷'very cold'. The juncture's meaning in this shout-out sentence is not clear, because besides occurring in front of the focused word, it also occurs at other words which should not have junctures. Junctures are functioned as a personality when its position occurs at the front of, or, before the adverbial word zhēnléng 真冷 'very cold'.

\section{CONCLUSION}

From the data analysis, the researcher finds out that the juncture patterns in all types of sentences (declarative/ question/command/shout-out), observed from the thematic meaning and the function, when an emphasized focus or instrument occurs in a word, then a juncture occurs before, or, at the beginning of the word. From the phonological point of view, juncture can occur between two syllables within one word, or between two words that consist of one syllable.

The junctures in Surabaya-citizen's speech occur more frequent between two words in a sentence than between two syllables within one word. Juncture variation exists in all types of sentences (declarative/question/command/shoutout). According to the thematic classification, both thematic and affective junctures occur as well. According to the function, there are instrument and interaction junctures The important thing is that, when a juncture occurs before the word, it is used to accentuate the meaning, for example like the meaning between a subject and a predicate, or a predicate and an object. A part of continuing juncture occurs between the combinations of two words, where the last word is a four-tone, one-tone, or light tone, or in other words the word has a high starting position (level 5). Continuing junctures have a time lapse of 0,011 to 0,066 second, but definitely those time lapses are not the shortest juncture in a sentence.

\section{REFERENCES}

Alwi, H., Dardjowidjojo, S., Lapoliwa, H., Moeliono, A.M. (2003). Tata Bahasa Baku Bahasa Indonesia (edisi ketiga). Jakarta: Balai Pustaka.

Chaer, A. (2007). Linguistik umum. Jakarta: Rineka Cipta.

Dörnyei, Z. (2007). Research methods in applied linguistics: Quantitative, qualitative, and mixed methodologies. New York: Oxford University Press.

Fáng, Y. (房玉清). (2008). Shíyòng Hànyǔ yǔfă (实用仅语吾去). Běijīng: Běijīng Yǔyán Dàxué Chūbănshè.

Halliday, M.A.K., \& Ruqaiya, H. (1976). Cohesion in English. London: Longman.

Hú, Y. (古蚝树). (1993). Xiàndài Hàny̌̌ (现代语). Hongkong: Joint Publishing Co., Ltd.

Hú, J. (胡吉成). (2006). Xiàndài Hànyǔ jīchǔ (现代议吾基称). Běijīñ: Běijīng Dàxué Chūbănshè.

Huáng, B., \& Liào, X. (黄官荣 夙预). (2005). Xiàndài Hànyǔ (现代双语. Běijīnng: Gāoděng Jiàoyù Chūbănshè.

Leech, G. (2003). Semantik (P. Partana, Trans.). Yogyakarta: Pustaka Pelajar Offset.

Liú, Y. (刘归华, Pān, W. (潘文娱), \& Gù, W. (故若莗. (2001). Shíyòng xiàndài Hànyǔ yǔfã (实册现代代吾吾去. Běijīng: Shāngwù Yìnshūguăn.

Miles, M. B., \& Huberman, A. M. (1992). Analisis data kualitatif. Jakarta: Universitas Indonesia.

Marsono. (2006). Fonetik. Yogyakarta: Gadjah Mada University Press.

Samarin,W. J. (1988). Field linguistics: A guide to linguistic field. (J.S. Badudu, Trans.). Yogyakarta: Kanisius.

Wú, J. (吴散文. (2000). Hànyǔ jiélüxué (汉语节聿学). Běijīng: Yǔwén Chūbănshè.

Xíng, F. (开福义), \& Wàng, G. (汛国胜). (2009). Xiàndài Hànyǔ (现代俉. Wúhàn: Huázhōng Shīfàn Dàxué Chūbănshè.

Xíng, F. (邢湢义. (2001). Xiàndài Hàny̌̌ (现代语). Běijīng: Gāoděng Jiàoyu Chūbănshè.

Xíng, G. (形公椀). (2003). Xiàndài Hànyǔ jiàochéng (现代议语教程). Tiānjīng: Nánkāi Dàxué Chūbănshè.

Yè, F. \& Xú, T. (叶蜚声徐通将. (1997). Yǔyánxué gāngyào (语言学纲婹). Běijīng: Běijīng Dàxué Chūbănshè. 